\title{
Serological Classification of Conjugative Plasmids by Indirect Haemagglutination
}

\author{
By N. H. FEILBERG JØRGENSEN, ${ }^{*}$ J. K. MØLLER AND A. STENDERUP \\ Institute of Medical Microbiology, University of Aarhus, Aarhus, Denmark
}

(Received 3 March 1982; revised 6 May 1982)

\begin{abstract}
The indirect haemagglutination reaction was evaluated in the classification of conjugative plasmids. A simple and sensitive method was worked out using pili and in some cases whole bacteria as antigens. Antibodies were prepared against pili coded for by plasmids from incompatibility groups IncFI, IncFII, IncI $\alpha$ and IncN. The antisera were tested against pili from 35 strains harbouring plasmids. The test differentiated clearly between plasmids from unrelated incompatibility groups, whereas cross-reaction occurred with closely related groups such as FI and FII. Minor antigenic variation could be seen within the IncFII group.
\end{abstract}

\section{INTRODUCTION}

Incompatibility testing is a widely used method for the classification of conjugative (selftransmissible) plasmids (Datta, 1979). This test is based on an examination of the stable coexistence of two plasmids (a plasmid to be tested and a reference plasmid) in a bacterial strain (clone) without selective pressure. Incompatibility is recognized by the loss of one of the plasmids. Therefore the plasmid to be tested must possess an easily identifiable character different from the reference plasmid.

Conjugation pili are specialized hair-like structures on the surface of bacterial cells. They serve an important role in the transfer of plasmid DNA from one bacterial cell to another. The conjugation pili seem to be unique for each incompatibility group, although the conjugation pili of a few incompatibility groups are related both genetically and in their molecular structure (Achtman \& Skurray, 1977).

Serological methods have seldom been used in the classification of conjugative pili, or the plasmids determining them. Ørskov \& Ørskov (1960) showed that cells of Escherichia coli K12 with an $\mathrm{F}$ plasmid were agglutinated by homologous antisera absorbed with $\mathrm{F}^{-}$bacteria. The antigen responsible for the reaction was later found to be identical with the F pilus (Ishibashi, 1967).

The early serological investigations on conjugation pili were based on slide or tube agglutination studies (Hirota et al., 1974; Kétyi \& Ørskov, 1969). Electronmicroscopic visualization of the reaction between antibodies and pili (Lawn, 1967; Lawn et al., 1967; Lawn \& Meynell, 1970; Bradley, 1980; Bradley et al., 1980), and the blocking of gene transfer caused by homologous anti-pili antibodies (Harden \& Meynell, 1972), have also been used in serological studies.

This paper is a report on the utility of the passive indirect haemagglutination reaction in a serological classification of conjugative plasmids. The serological investigations were performed with antibodies against pili coded for by plasmids belonging to the incompatibility groups IncFI, IncFII, IncI $\alpha$ and IncN.

\section{METHODS}

Bacterial host strains and plasmids. An autotrophic pilus-free and flagellum-free derivative of Escherichia coli K12, JE2217 (Helmuth \& Achtman, 1978) was used as the only host strain for the plasmids in the immunization 
procedure. Incompatibility reactions and haemagglutination assays were performed using E. coli J62-1 (Pro ${ }^{-}$ $\mathrm{His}^{-} \mathrm{Trp}^{-} \mathrm{Str}^{R} \mathrm{Nal}^{\mathrm{R}} \mathrm{Lac}^{-}$) obtained from Dr N. Datta, Hammersmith Hospital, London, as the plasmid host strain. In a few experiments the original wild-type strain as well as JE2217 were also used. Salmonella panama I was obtained from J. van Embden, Rijks Instituut voor de Volkgezondheid, Bilthoven, The Netherlands. The other wild-type strains were isolated in our laboratory (Møller, 1980). These strains were used only when they contained plasmids.

The plasmids are reference type plasmids or plasmids isolated and characterized in our laboratory. They were transferred from the original host to the new host as described by Møller (1980). The F plasmid was provided by $\mathrm{Dr}$ I. Ørskov, State Serum Institute, Copenhagen, Denmark; R386, NRI, Idrd16, R144, R64drd11 and N3T were obtained from Dr N. Datta; P307 from Dr H. Williams Smith, Houghton Poultry Research Station, Houghton, U.K.; SPI from Dr J. van Embden; and R1drd19 from Dr K. Nordstrøm, University of Odense, Denmark. The other plasmids were isolated in our laboratory (Møller et al., 1976).

Production of pilus-specific antisera. Antigens for the immunization of rabbits were prepared from tryptone broth cultures of JE2217 possessing one of the four reference plasmids [R386 (IncFI), R $1 d r d 19$ (IncFII), Idrd16 (IncI $\alpha$ ), $\mathrm{N} 3 \mathrm{~T}(\mathrm{IncN})]$. The bacteria were grown under aeration to late exponential phase, collected by centrifugation ( $5 \mathrm{~min}$ at $3000 \mathrm{~g}, 4{ }^{\circ} \mathrm{C}$ ), gently washed twice in phosphate-buffered saline (PBS) $\mathrm{pH} 7 \cdot 4$, containing $0.02 \%$ (w/v) sodium azide, and then suspended at a concentration of $5 \times 10^{8}$ bacteria $\mathrm{ml}^{-1}$ in PBS pH $7 \cdot 4$, containing $0.5 \%(\mathrm{v} / \mathrm{v})$ formalin.

Albino rabbits were immunized according to the method of Ernø et al. (1973). The serum was absorbed with JE2217 repeatedly until no reaction was seen in an indirect haemagglutination reaction with undiluted serum or serum diluted $1 / 10$; it was inactivated $\left(30 \mathrm{~min}, 56^{\circ} \mathrm{C}\right)$ and absorbed with sheep erythrocytes. All absorption experiments were done by conventional methods.

Preparation of antigens for haemagg/utination assay. For antigen preparations bacteria were grown under aeration in tryptone broth with $0.2 \%(\mathrm{w} / \mathrm{v})$ glucose and necessary amino acids for $8 \mathrm{~h}$ or on the same medium plus agar for $18 \mathrm{~h}$. Broth cultures were centrifuged and the sediment suspended in PBS, washed twice and finally suspended in PBS with $0.02 \%$ sodium azide. The bacteria grown on agar were scraped off and treated in the same way. The pili were liberated from the bacterial cells by mixing with sucrose $(30 \%$, w/v of the bacterial suspension) in a rotatory shaker ( 200 r.p.m., $30 \mathrm{~min}$ ), removing the cells by centrifugation $\left(15 \mathrm{~min}\right.$ at $2000 \mathrm{~g}, 4{ }^{\circ} \mathrm{C}$ ), and the sucrose by dialysis against PBS. The protein concentration of the pilus suspension was determined by the Lowry method, and adjusted to at least $50 \mu \mathrm{g} \mathrm{ml} \mathrm{m}^{-1}$.

Indirect haemagglutination assay. Freshly drawn sheep erythrocytes (in Alsevers solution) were washed three times in PBG $\left(0.114 \mathrm{M}-\mathrm{Na}_{2} \mathrm{HPO}_{4}, 0.036 \mathrm{M}-\mathrm{KH}_{2} \mathrm{PO}_{4}\right.$ and $2.6 \%$ glucose, $\left.\mathrm{pH} 7.2\right)$ and suspended in PBG to give a $20 \%$ solution. Equal volumes of sheep erythrocytes and $0 \cdot 2 \%(\mathrm{v} / \mathrm{v})$ glutaric aldehyde were mixed for $15 \mathrm{~min}$ at $37{ }^{\circ} \mathrm{C}$, washed in $0.9 \%(\mathrm{w} / \mathrm{v})$ sodium chloride and PBS, and suspended at a concentration of $25 \%$ in PBS supplemented with $0.1 \%$ sodium azide. Before use the erythrocytes were washed twice in PBS and resuspended in the same volume of PBS with $0.1 \%$ sodium azide and coated with antigen overnight while rotating slowly at room temperature.

The amount of pilus antigen needed for optimal coating of the erythrocytes was determined in a check-board titration using homologous antisera undiluted, diluted to $1 / 10$ and to $1 / 100$, and twofold dilutions of homologous antigen (pili). When whole bacterial cells were used the amount was determined in a similar way.

After coating, excess antigen was removed by three gentle washes with PBS. If not used immediately $(2 \%$ mixture in PBS), the erythrocytes were kept in PBS with $50 \%(\mathrm{v} / \mathrm{v})$ glycerol for no more than a week.

The assay was performed in a dispensable microvial (Nunc). The dilution liquid was PBS with $1 \%$ rabbit serum $(1 \% \mathrm{SA})$ inactivated and absorbed against sheep erythrocytes; $25 \mu 11 \%$ SA was dripped into each vial. Antiserum $(25 \mu \mathrm{l})$ was added to the first vial and serial dilutions were made. Then, $25 \mu \mathrm{l}$ of coated erythrocytes were added to each of the vials. Positive and negative controls were included.

The results were read visually after $2 \mathrm{~h}$ at room temperature. The end point was taken as being when the erythrocytes had formed a carpet covering more than three-quarters of the bottom of the vial.

\section{RESULTS}

The serological results are recorded in Tables 1, 2,3 and 4. Table 1 gives the results obtained when different antigen preparations from strains with plasmids belonging to two incompatibility groups ( $\mathrm{N}$ and $\mathrm{I})$ were tested against $\mathrm{N}$ pilus-specific antibodies. The pilus-free strain (JE2217) and the K12 (J62-1) strain that possesses chromosomally-coded pili (Salit \& Gotschlich, 1977) were also included as antigens. Plasmid pJM14 does not belong to IncN or IncI, but is otherwise unclassified. The highest titres were obtained with homologous pilus antigens (N3T and pJM18, IncN). The titres varied with the antigen preparation; the highest 
Table 1. Indirect haemagglutination assay using $N$ pilus-specific antibodies and different antigen preparations from Escherichia coli strains with homologous and heterologous plasmids

\begin{tabular}{|c|c|c|c|c|c|c|}
\hline \multirow{2}{*}{\multicolumn{2}{|c|}{ Antigen source }} & \multirow{3}{*}{$\begin{array}{l}\text { Incompatibility } \\
\text { group }\end{array}$} & \multicolumn{4}{|c|}{ Antibody titres against antigen preparations of: } \\
\hline & & & \multirow{2}{*}{$\begin{array}{c}\text { Broth-grown } \\
\text { bacteria }\end{array}$} & \multirow{2}{*}{$\begin{array}{l}\text { Pili from } \\
\text { broth-grown } \\
\text { bacteria }\end{array}$} & \multirow{2}{*}{$\begin{array}{c}\text { Agar-grown } \\
\text { bacteria }\end{array}$} & \multirow{2}{*}{$\begin{array}{l}\text { Pili from } \\
\text { agar-grown } \\
\text { bacteria }\end{array}$} \\
\hline Strain & Plasmid & & & & & \\
\hline JE2217 & N3T & Inc $N$ & 384 & 768 & 96 & 768 \\
\hline $\mathrm{J} 62-1$ & N3T & IncN & 384 & 768 & 192 & 768 \\
\hline $\mathrm{J} 62-1$ & pJM18 & IncN & 192 & 768 & 96 & 768 \\
\hline $\mathrm{J} 62-1$ & $\mathrm{pJM} 2 \mathrm{I}$ & $\operatorname{lnc} \mathrm{I} \alpha$ & 96 & 96 & 6 & 0 \\
\hline $\mathrm{JE} 2217$ & pJM14 & Not IncN or Inc $\alpha$ & 24 & 48 & 12 & 6 \\
\hline J62-1 & pJM 14 & Not IncN or Inc $\alpha$ & 0 & ND & 0 & ND \\
\hline JE2217 & Plasmid-free & - & 0 & - & 0 & - \\
\hline J62-1 & Plasmid-free & - & 48 & 48 & 0 & 0 \\
\hline
\end{tabular}

ND, Not done.

Table 2. Indirect haemagglutination reaction between $N$ pili antigens from different host strains and $N$ pili antibodies

\begin{tabular}{lllr}
\multicolumn{1}{c}{ Host strain } & \multicolumn{1}{c}{} & \multicolumn{2}{c}{ pili } \\
& \multicolumn{1}{c}{ Plasmid } & \multicolumn{1}{c}{$\begin{array}{c}\text { Incompatibility } \\
\text { group }\end{array}$} & $\begin{array}{c}\text { antibody } \\
\text { titre }\end{array}$ \\
Escherichia coli K12 (J62-1) & N3T & IncN & 768 \\
Escherichia coli K12 (JE2217) & N3T & IncN & 768 \\
Escherichia coli K12 (CR34) & SPI & IncN & 384 \\
Salmonella panama type I (MMCA 496)* & SPI & IncN & 192 \\
Enterobacter cloaceae (MMCA 268)* & pJM18 & IncN & 384 \\
Escherichia coli K12 (JE2217) & pJM18 & IncN & 384 \\
Escherichia coli K12 (J62-1) & pJM18 & IncN & 384 \\
Escherichia coli K12 (J62-1) & pJM56 & IncN & 384 \\
Escherichia coli K12 (J62-1) & pJM57 & IncFII & 0 \\
Escherichia coli wild-type (MMCA 255)* & pJM56, pJM57 & IncN, IncFII & 192
\end{tabular}

*Abbreviation: MMCA, Medical Microbiological Collection, Aarhus, Denmark.

titres were found with pili as antigens. Broth-grown bacteria showed a higher titre than bacteria grown on agar. With the heterologous plasmid (pJM21, IncI $\alpha$ ) and the unclassified plasmid pJM14, reactions were not significantly different from those obtained with the plasmid-free strain (J62-1). With the plasmid-free strain JE2217 no reaction was seen. With broth-grown J621 as antigen a low titre was recorded, whether with whole bacterial cells, or preparations of the chromosomally-coded pili. This may be caused by non-specific adherence of the erythrocytes and the chromosomally-coded pili (Salit \& Gotschlich, 1977).

Table 2 contains the results of experiments using antibodies against IncN pili, and antigens which consisted of pilus preparations made from eight different strains, all containing (with one exception) IncN plasmids. Only minor variations could be seen in titres regardless of the host strain and IncN plasmid. The presence of an unrelated plasmid (pJM57, IncFII) with which there was no reaction, together with an IncN plasmid (pJM56), did not have a significant influence on the titre.

The value of the indirect haemagglutination assay was examined further using IncFI, IncFII, IncI $\alpha$ and IncN antisera against pilus antigens isolated from a number of strains harbouring conjugative plasmids. These were reference plasmids with known incompatibility grouping, and plasmids isolated from wild-type enterobacterial strains in our laboratory.

The results of experiments using pili coded by $\mathrm{Fi}^{+}(\mathrm{F})$ plasmids as antigens are listed in Table 3 , and those using the $\mathrm{Fi}^{-}(\mathrm{F})$ plasmid-determined pili are listed in Table 4. From Table 3 it can be seen that no reaction could be detected betweem IncI $\alpha$ and IncN antisera and the antigens 
Table 3. Indirect haemagglutination reaction of $\mathrm{Fi}^{+}(F)$ plasmids

\begin{tabular}{lccccc} 
& & \multicolumn{5}{c}{$\begin{array}{c}\text { Antibody titres } \\
\text { Pilus antigens }\end{array}$} & $\begin{array}{l}\text { Incompatibility } \\
\text { group }\end{array}$ & IncFI & IncFII & IncI $\alpha$ & IncN \\
\cline { 2 - 6 } F & IncFI & 768 & 192 & 0 & 0 \\
R386 & IncFI & 768 & 192 & 0 & 0 \\
P307 & IncFI & 768 & 192 & 0 & 0 \\
pJM11 & IncFI & 768 & 192 & 0 & 0 \\
pJM26 & IncFI & 384 & 192 & 0 & 0 \\
R1drd19 & IncFII & 384 & 768 & 0 & 0 \\
NRI & IncFII & 384 & 192 & 0 & 0 \\
pJM3 & IncFII & 192 & 768 & 0 & 0 \\
pJM6 & IncFII & 192 & 192 & 0 & 0 \\
pJM12 & IncFII & 96 & 192 & 0 & 0 \\
pJM19 & IncFII & 192 & 384 & 0 & 0 \\
pJM20 & IncFII & 96 & 192 & 0 & 0 \\
pJM22 & IncFII & 192 & 768 & 0 & 0 \\
pJM24 & IncFII & 192 & 384 & 0 & 0 \\
pJM15 & IncFII and IncT & 96 & 384 & 0 & 0 \\
pJM17 & IncFII and IncT & 384 & 768 & 0 & 0 \\
pJM7 & Not IncFI or IncFII & 96 & 96 & 0 & 0 \\
pJM8 & Not IncFI or IncFII & 192 & 384 & 0 & 0 \\
pJM25 & Not IncFI or IncFII & 192 & 768 & 0 & 0 \\
pJM55 & Not IncFI or IncFII & 192 & 96 & 0 & 0 \\
pJM60 & Not IncFI or IncFII & 192 & 380 & 0 & 0 \\
& & & & &
\end{tabular}

Table 4. Indirect haemagglutination reactions of $F^{-}(F)$ plasmids

\begin{tabular}{|c|c|c|c|c|c|}
\hline \multirow[b]{2}{*}{ Pilus antigens } & \multirow{2}{*}{$\begin{array}{l}\text { Incompatibility } \\
\text { group }\end{array}$} & \multicolumn{4}{|c|}{$\begin{array}{l}\text { Antibody titres } \\
\text { against conjugation pili from: }\end{array}$} \\
\hline & & IncFI & IncFII & IncI $\alpha$ & $\operatorname{IncN}$ \\
\hline $\mathrm{I} d r d 16$ & $\operatorname{Incl} \alpha$ & 0 & 0 & 768 & 0 \\
\hline R144 & $\operatorname{IncI} \alpha$ & 0 & 0 & 768 & 0 \\
\hline R64drd11 & $\operatorname{IncI} \alpha$ & 0 & 0 & 192 & 0 \\
\hline pJM21 & $\operatorname{IncI} \alpha$ & 0 & 0 & 768 & 0 \\
\hline pJM23 & IncI?* & 0 & 0 & 96 & 0 \\
\hline N3T & $\operatorname{IncN}$ & 0 & 0 & 0 & 768 \\
\hline SPI & IncN & 0 & 0 & 0 & 768 \\
\hline pJM18 & $\operatorname{IncN}$ & 0 & 0 & 0 & 384 \\
\hline $\mathrm{pJM} 56$ & IncN $N$ & 0 & 0 & 0 & 384 \\
\hline pJM61 & IncN & 0 & 0 & 0 & 768 \\
\hline pJM4 & Inc?† & 0 & 0 & 0 & 0 \\
\hline pJM9 & Inc?† & 0 & 0 & 0 & 0 \\
\hline $\mathrm{pJM} 14$ & Inc?† & 0 & 0 & 0 & 0 \\
\hline $\mathrm{pJMl6}$ & Inc?† & 0 & 0 & 0 & 0 \\
\hline
\end{tabular}

* Strains possessing this plasmid multiply the IncI-specific phage If 1, but are compatible with plasmids from IncI $\alpha$ or IncI $\gamma$.

$\dagger$ Compatible with IncI $\alpha$, IncI $\gamma$, IncN, IncP, IncT; and IncW plasmids.

used. A high titre was always observed between IncFI antisera and pilus antigens of IncFI plasmids (a homologous reaction). Significantly different titres were sometimes observed in the homologous reaction between IncFII pili and the corresponding antisera. The heterologous reactions (IncFI antigens versus IncFII antisera or IncFII antigens versus IncFI antisera) generally gave lower titres than in the homologous reactions. Five plasmids (pJM7, pJM8, 
pJM25, pJM55 and pJM60) were compatible with IncFI and IncFII plasmids, but otherwise untypable (Møller, 1980). The titres obtained indicate that these plasmids belong to the $F$ complex but to other incompatibility groups within the complex.

The results in Table 4 show that no reaction could be detected between IncFI and IncFII antisera and the antigens used. With one exception (R64drd11 pili versus IncI $\alpha$ antisera) the same high titres were observed between IncI $\alpha$ antisera and pili of the IncI $\alpha$ plasmids as were obtained with IncN antisera of pili of IncN plasmids. A significantly lower titre was seen when pili from a strain harbouring plasmid pJM23 was probed against IncI $\alpha$ antiserum. Plasmid pJM23 does not belong to the I $\alpha$ or the I $\gamma$ incompatibility groups; however, strains with pJM23 are sensitive towards the I pilus specific phage If 1 , and this plasmid has a high percentage of DNA homology with the IncI $\alpha$ reference plasmid Idrd16 (Møller et al., 1978).

No reaction could be found in the assay with plasmids pJM4, pJM9, pJM14 and pJM16, which are of unknown incompatibility group, but do not belong to IncFI, IncFII, IncI $\alpha$, IncI $\gamma$, IncN, IncP, IncT or IncW.

\section{DISCUSSION}

Serological methods have seldom been applied in the classification of conjugative plasmids, and have been limited exclusively to derepressed plasmids. Thus, slide agglutination of bacteria as well as electron microscopic visualization of the reactions have been used, but with little success.

Indirect haemagglutination has apparently never been applied before in the serological classification of conjugative plasmids. It is, however, easily performed. By using pilus preparations as antigens the method is independent of whether the plasmids are repressed or derepressed. The non-specific adherence between chromosomally-coded pili and the erythrocytes is considered to be negligible. The method may be performed with pili liberated from wildtype strains and is unaffected by either the presence of a coexisting unrelated plasmid or the simultaneous presence of two incompatibility determinants on one plasmid (e.g. the IncFII and Inc $\mathrm{T}$ determinants on $\mathrm{pJM} 15$ ).

The method unequivocally distinguishes between groups of plasmids from different incompatibility complexes (IncI, IncF and IncN). These groups were originally chosen because of their frequent occurrence and were later shown to represent three morphological groups (Bradley, 1980). There are, however, limitations in distinguishing between plasmids from different incompatibility groups within the $\mathrm{F}$ complex. This is not surprising because these pilus proteins are very much alike (Kennedy et al., 1977; Achtman et al., 1978). The variable results within the $\mathrm{F}$ complex and in a single case in the I complex (R64drd11) may be explained by minor antigenic variations (Lawn \& Meynell, 1970; Lawn et al., 1967; Bradley, 1980). Further investigations will show whether it is possible to use different combinations of absorbed antisera to define plasmids within such groups. However, we are dealing with two different biological phenomena. The pilus is active in transfer and as a receptor for specific phage, whereas incompatibility is closely associated with replication.

The $\mathrm{Fi}^{+}(\mathrm{F})$ plasmids not belonging to groups IncFI or IncFII, which showed positive reactions with FI and FII antisera, must belong to other groups in the F complex. The surprisingly high titre noted in one instance (pJM25) might support the assumption that two different incompatibility groups share a common pilus.

The $\mathrm{F}^{-}(\mathrm{F})$ plasmids not belonging to IncFI, IncFII, IncI $\alpha$ or IncN, which showed no reaction with the antisera, cannot possess pili related to groups F, I or N. Neither do they possess a significant DNA homology with plasmids from these groups (Møller et al., 1978; N. H. Feilberg Jørgensen, unpublished results).

Drs Ida Ørskov, H. Williams Smith, R. Helmuth, N. Datta, J. van Embden, and K. Nordstrøm are thanked for supplying strains and plasmids. This work was supported by grant no. 512-10279 from the Danish Medical Research Council. 


\section{REFERENCES}

ACHTMAN, M. \& SKurRay, R. (1977). A redefinition of the mating phenomenon in bacteria. In Microbial Interactions (Receptors and Recognition), Series B, vol. 3, pp. 235-279. Edited by J. L. Reissig. London: Chapman \& Hall.

ACHTMan, M., KuseceK, B. \& Timmis, K. (1978). Tra cistrons and proteins encoded by Escherichia coli antibiotic resistance plasmid R6-5. Molecular and General Genetics 63, 169-179.

BRADLEY, D. E. (1980). Morphological and serological relationship of conjugative pili. Plasmid 4, 155-169.

Bradley, D. E., Taylor, D. E. \& Cohen, D. R. (1980). Specification of surface mating systems among conjugative drug resistance plasmids in Escherichia coli K-12. Journal of Bacteriology 143, 1466-1470.

DatTA, N. (1979). Plasmid classification: incompatibility grouping. In Plasmids of Medical, Environmental and Commercial Importance, pp. 3-12. Edited by K. N. Timmis \& A. Pühler. Amsterdam: ElsevierNorth Holland.

Erng, H., Jurmanová, K. \& Leach, R. H. (1973). Bovine mycoplasmas: a serological study by the metabolic inhibition test. Acta veterinaria scandinavica 14, 511-523.

HARDEN, V. \& MEYNELl, E. W. (1972). Inhibition of gene transfer by antiserum and identification of serotype of sex pili. Journal of Bacteriology 109, 1067-1074.

Helmuth, R. \& Achtman, M. (1978). Cell-cell interactions in conjugating Escherichia coli: purification of $\mathrm{F}$ pili with biological activity. Proceedings of the National Academy of Sciences of the United States of America 75, 1237-1241.

Hirota, Y., Nishimura, Y., Ørskov, F. \& ØrSkov, I. (1964). Effect of drug-resistance factor $R$ on the $F$ properties of Escherichia coli. Journal of Bacteriology 87, $341-351$.
ISHIBASHI, M. (1967). F pilus as $\mathrm{f}^{+}$antigen. Journal of Bacteriology 93, 379-389.

Kennedy, N., Bentin, L., Achtman, M. \& Skurray, R. (1977). Conjugation proteins encoded by the $F$ sex factor. Nature, London 270, 580-585.

KÉTYI, I. \& ØRSKOV, I. (1969). Studies on the antigenic structure of sex fimbriae carried by a strain of Shigella flexneri 4b. Acta pathologica et microbiologica scandinavica 77, 299-308.

LAWN, A. M. (1967). Simple immunological labelling method for electron microscopy and its application to the study of filamentous appendages of bacteria. Nature, London 214, 1151-1152.

LAWN, A. M. \& MEYNELL, E. (1970). Serotypes of sex pili. Journal of Hygiene 68, 683-694.

Lawn, A. M., Meynell, E., Meynell, G. \& Datta, N. (1967). Sex pili and the classification of sex factors in Enterobacteriaceae. Nature, London 216, 343-346.

Møller, J. K. (1980). Infectious drug resistance. Ph.D. thesis (in Danish), University of Aarhus, Denmark.

Møller, J. K., BaK, A. L., Christiansen, C., Christiansen, G. \& Stenderup, A. (1976). Extrachromosomal deoxyribonucleic acid in $\mathbf{R}$ factorharboring Enterobacteriaceae. Journal of Bacteriology 125, 398-403.

Møller, J. K., Jørgensen, N. H. F., Christiansen, C., Christiansen, G., BaK, A. L. \& Stenderup, A. (1978). Characterization of plasmids from wild-type Enterobacteriaceae. In Microbiology - 1978, pp. 257261. Edited by D. Schlessinger. Washington, D.C.: American Society for Microbiology.

ØRSKOV, I. \& ØRSKOV, F. (1960). An antigen termed $\mathrm{f}^{+}$ occurring in $\mathrm{F}^{+}$E. coli strains. Acta pathologica et microbiologica scandinavica 48, 37-46.

Salit, I. E. \& Gotschlich, E. C. (1977). Hemagglutination by purified type I Escherichia coli pili. Journal of Experimental Medicine 146, 1169-1181. 